\title{
The influence of understanding of reading graphs and understanding sentence on writing ability
}

\author{
Priyono*) \\ Universitas Indraprasta PGRI \\ *) Correspondences author: Jalan Raya Tengah No. 80, RT.9/RW.8, Gedong, Pasar Rebo, RT.1/RW.3, Gedong, \\ Kota Jakarta Timur, Daerah Khusus Ibukota Jakarta 13760, Indonesia; e-mail: ryo.ahimsa@ yahoo.com
}

\begin{abstract}
The purpose of this research is to understand how much the effect of chart and sentence understanding to writing ability of private junior high school student in East Jakarta. This research used quantitative descriptive method with multiple correlation test. Based data analysis can conclude that; 1 . There is significant effect between chart (X1) and sentence understanding (X2) to writing ability (X3). From regression coefficient significant result shows by score $\mathrm{Sig}=0,001$ and Fhitung $=8,374$ while Ftabel $=2,79$ so that the score $\operatorname{Sig}=<0,05$ and Fhitung $>$ Ftabel shows that regression is significant and means that there is a positive effect between independent variable X1(chart understanding) and X2 (sentence undertstanding) to dependent variable Y (writing ability).
\end{abstract}

Keywords: Chart, Sentence, Writing.

Article History: Received: 09/02/2017; Revised: 03/03/2017; Accepted: 15/04/2017; Published: 05/05/2017

How to Cite (MLA $7^{\text {th }}$ ): Priyono. "The influence of understanding of reading graphs and understanding sentence on writing ability." Hortatori: Jurnal Pendidikan Bahasa dan Sastra Indonesia 1.1 (2017): 57-60. Print/Online. Copyrights Holder: Priyono. First Publication: Hortatori: Jurnal Pendidikan Bahasa dan Sastra Indonesia (2017).

\section{Pendahuluan}

Dalam belajar bahasa, ada empat aspek keterampilan berbahasa yang harus dipelajari, yaitu keterampilan membaca, keterampilan menulis, keterampilan menyimak, dan keterampilan berbicara. Namun, dalam praktiknya teori-teori kebahasaan lebih banyak dipelajari daripada keterampilan berbahasa. Padahal, teori-teori kebahasaan digunakan untuk menunjang keterampilan berbahasa baik yang disampaikan secara lisan maupun secara tulisan.

Keempat aspek keterampilan berbahasa tersebut dapat dibagi menjadi dua bagian, yaitu keterampilan reseptif dan keterampilan produktif. Keterampilan reseptif meliputi keterampilan menyimak dan membaca. Dikatakan keterampilan reseptif karena kedua keterampilan tersebut bersifat menerima atau mendapatkan. Artinya, melalui kedua keterampilan ini kita dapat memperoleh segala informasi atau memperoleh wawasan pengetahuan yang lebih luas dan dapat meningkatkan kemampuan intelektual. Keterampilan produktif meliputi keterampilan berbicara dan menulis. Keterampilan produktif bersifat menghasilkan atau menggunakan. Artinya, kedua keterampilan tersebut menuntut penggunaan bahasa sebagai alat komunikasi. Baik keterampilan reseptif maupun keterampilan produktif, keduanya mempunyai hubungan yang erat. Keterampilan produktif tidak dapat dimiliki tanpa melakukan keterampilan reseptif. Keterampilan reseptif dilakukan agar mempunyai referen atau pengalaman yang dapat dijadikan bahan untuk melakukan keterampilan produktif.

Membaca sebagai salah satu keterampilan berbahasa adalah kegiatan yang sering dilakukan orang. Saat ini orang membaca tidak lagi terikat ruang dan waktu, orang dapat membaca di mana saja dan kapan saja. Membaca dilakukan orang untuk berbagai tujuan, terutama untuk mencari informasi yang dibutuhkan. 
Seorang pembaca yang baik tidak hanya mampu membaca teks bacaan, tetapi juga harus pandai menyerap informasi yang terkandung dalam grafik, tabel, diagram, dan peta. Apalagi di era informasi ini, untuk menjelaskan suatu maksud, orang cenderung menggunakan grafik dan alat bantu lainnya. Ceramah dan presentasi terasa kurang lengkap apabila tidak menggunakan grafik. Laporan jurnalis dalam surat kabar menggunakan grafik untuk memvisualisasikan laporannya. Selebaran atau buletin penjualan yang dibagikan kepada konsumen pun dilengkapi dengan grafik-grafik.

Melihat kenyataan tersebut, grafik tidak lagi dipandang orang sebagai sesuatu yang rumit dan sulit dipahami, tetapi sebagai sesuatu yang menarik dan efektif untuk berbagai keperluan. Grafik yang dihadirkan penulis dapat menghemat waktu karena mempercepat komunikasi kepada pembacanya. Dalam grafik disajikan fakta-fakta dalam konteks, menunjukkan fakta-fakta itu secara lebih mudah, serta membuat hidup konsep-konsep yang diusulkan.

Grafik adalah bentuk informasi nonverbal, diperlukan bahasa untuk memaparkan fakta dan data tersebut. Oleh sebab itu, grafik dapat dijadikan media untuk melatih dan meningkatkan kemampuan berbahasa siswa, terutama kemampuan menulis paparan. Pada dasarnya, grafik merupakan paparan yang divisualkan.

Tulisan paparan yang dibuat siswa melalui pemahaman grafik dapat dijadikan alat untuk mengukur kemampuan siswa dalam menyerap informasi yang tersaji dalam grafik selain pertanyaan-pertanyaan mengenai grafik yang diajukan guru. Dengan demikian, ada dua kemampuan yang secara langsung dimiliki siswa melalui grafik, yaitu kemampuan membaca dan kemampuan menulis.

Menulis merupakan salah satu aspek keterampilan berbahasa yang penting bagi siswa, baik di sekolah maupun dalam kehidupan masyarakat. Keberhasilan siswa dalam mengikuti kegiatan belajar mengajar di sekolah banyak ditentukan oleh kemampuan siswa tersebut dalam menulis. Oleh karena itu, pengajaran keterampilan menulis memiliki kedudukan yang sangat strategis dalam pendidikan dan pengajaran.

Dari uraian di atas, peneliti tertarik untuk meneliti pengaruh pemahaman membaca grafik dan pemahaman kalimat terhadap kemampuan menulis siswa SMP Swasta di Jakarta Timur. Dari penelitian ini akan diketahui seberapa besar pengaruh antara ketiga variabel tersebut. Apakah pengaruhnya signifikan atau sebaliknya.

\section{Metode}

Metode yang digunakan dalam penelitian ini adalah survai dengan teknik korelasional. Variabel penelitian ini terdiri atas variabel terikat, yaitu kemampuan menulis $(\mathrm{Y})$ dan dua variabel bebas, yaitu pemahaman grafik (X1) dan pemahaman kalimat (X2 maka model konstelasi hubungan antarvariabel dalam penelitian ini adalah sebagai berikut :

Keterangan: Variabel Bebas (X1): pemahaman grafik

Variabel Bebas (X2): pemahaman kalimat

Variabel Terikat (Y): kemampuan menulis

Dalam penelitian ini yang menjadi populasi terjangkau adalah siswa kelas VII di SMP Diponegoro 1 Jakarta yang berjumlah 4 kelas. Dari 4 kelas yang dijadikan populasi tersebut, yang dijadikan sampel adalah siswa 1 kelas yang berjumlah 29 siswa dan satu kelas siswa kelas VII SMP At Taubah yang berjumlah 24. Jadi, total sampel adalah 53 siswa.

Hipotesis merupakan dugaan sementara atas rumusan masalah. Untuk itu hipotesis harus diuji kebenarannya secara empiris. Pengujian hipotesis ini diperlukan karena data yang dikumpulkan melalui sampel merupakan data perkiraan dan hipotesis merupakan anggapan atau dugaan yang belum tentu kebenarannya. Untuk pengujian hipotesis digunakan uji t, dengan kriteria sebagai berikut:

Jika t hitung > t tabel, maka Ha diterima atau Ho ditolak.

Jika thitung < t tabel, maka Ha ditolak atau Ho diterima. 


\section{Hasil dan Diskusi}

\section{Pengaruh pemahaman grafik dan pemahaman kalimat secara bersama-sama terhadap kemampuan menulis}

Dari deskripsi data setelah dilakukan analisis korelasi diperoleh koefisien korelasi sebesar 0,501 setelah dilakukan pengujian dengan program SPSS terbukti bahwa koefisien korelasi tersebut signifikan. Hal ini berarti bahwa terdapat pengaruh variabel bebas $X_{1}$ (pemahaman grafik) dan $X_{2}$ (pemahaman kalimat) secara bersama-sama terhadap variabel terikat $\mathrm{Y}$ (kemampuan menulis ).

Dari analisis regresi diperoleh persamaan garis regresi $\widehat{\mathrm{Y}}=37,858+0,369 \mathrm{X}_{1}+0,211 \mathrm{X}_{2}$. Nilai konstanta $=37,858$ menunjukkan bahwa siswa dengan pemahaman grafik dan pemahaman kalimat paling rendah sulit untuk bisa meraih kemampuan menulis yang baik, sedangkan nilai koefisien regresi sebesar 0,369 dan 0,211 menunjukkan bahwa terdapat pengaruh positif variabel bebas $\mathrm{X}_{1}$ (pemahaman grafik) dan $\mathrm{X}_{2}$ (pemahaman kalimat) secara bersama-sama terhadap variabel terikat $\mathrm{Y}$ (kemampuan menulis). Setelah dilakukan pengujian linieritas garis regresi dengan menggunakan program SPSS, diperoleh bahwa garis regresi tersebut linier.

Dari pengujian signifikansi koefisien regresi yang juga dilakukan dengan program SPSS diperoleh bahwa koefisien regresi tersebut signifikan, yaitu ditunjukkan oleh nilai $\mathrm{Sig}=0.001$ dan $\mathrm{F}_{\text {hitung }}=8,374$ sedangkan $\mathrm{F}_{\text {tabel }}=2,79$ sehingga nilai Sig $>0,05$ dan $\mathrm{F}_{\text {hitung }}>\mathrm{F}_{\text {tabel }}$ atau regresi tersebut signifikan, yang berarti benar bahwa tidak terdapat pengaruh yang positif variabel bebas $X_{1}$ (pemahaman grafik) dan $X_{2}$ (pemahaman kalimat) secara bersama-sama terhadap variabel terikat $\mathrm{Y}$ (kemampuan menulis).

\section{Pengaruh pemahaman grafik terhadap kemampuan menulis}

Dari pengujian hipotesis diperoleh bahwa nilai $\operatorname{Sig}=0.003$ dan $t_{\text {hitung }}=3,126$ sedangkan $t_{\text {tabel }}=$ 2,000. Karena nilai Sig $<0,05$ dan $t_{\text {hitung }}>t_{\text {tabel }}$ maka $\mathrm{H}_{0}$ di tolak yang berarti terdapat pengaruh yang signifikan variabel bebas $\mathrm{X}_{1}$ (Pemahaman grafik) terhadap variabel terikat $\mathrm{Y}$ (Kemampuan menulis).

\section{Pengaruh pemahaman kalimat terhadap kemampuan menulis siswa}

Dari pengujian hipotesis diperoleh bahwa nilai $\mathrm{Sig}=0.026$ dan $\mathrm{t}_{\text {hitung }}=2,294$ sedangkan $\mathrm{t}_{\text {tabel }}=$ 2,000. Karena nilai Sig $<0,05$ dan $t_{\text {hitung }}>\mathrm{t}_{\text {tabel }}$ maka $\mathrm{H}_{0}$ di tolak yangberarti terdapat pengaruh yang signifikan variabel bebas $\mathrm{X}_{2}$ (Pemahaman kalimat) terhadap variabel terikat $\mathrm{Y}$ (Kemampuan menulis)

\section{Simpulan}

Setelah diadakan penelitian dan analisis data tentang " Pengaruh Pemahaman Membaca Grafik dan Pemahaman Kalimat terhadap Kemampuan Menulis" dapat ditarik simpulan (1)Terdapat pengaruh yang signifikan secara bersama-sama pemahaman grafik (X1) dan pemahaman kalimat (X2) terhadap kemampuan menulis eksposisi (Y) (2)Terdapat pengaruh yang signifikan pemahaman grafik (X1) terhadap kemampuan menulis eksposisi (Y); (3)Terdapat pengaruh yang signifikan pemahaman kalimat (X2) terhadap kemampuan menulis eksposisi (Y).

\section{Ucapan Terima Kasih}

Terima kasih kepada semua pihak yang membantu penulis dalam menyelesaikan artikel hasil riset ini sehingga bisa diterbitkan di Jurnal Hortatori.

\section{Daftar Rujukan}

Hasan, A, dkk. Tata bahasa baku bahasa Indonesia. Jakarta: Balai Pustaka, 2008. Print

Keraf, G. Eksposisi dan deskripsi. Jakarta: Gramedia, 1995. Print.

Kridalaksana, H. Kamus linguistik. Jakarta: Gramedia, 2008. Print.

Nurgiyantoro, B. Penilaian dalam pengajaran bahasa dan sastra. Yogyakarta: BPFE, 1987. Print.

Putrayasa, I.B. Jenis kalimat dalam bahasa Indonesia. Bandung: PT Refika Aditama, 2009. Print. 
60 The influence of understanding of reading graphs and understanding sentence on writing ability

Supranto, J. Statistik, teori, dan aplikasi. Jakarta: Erlangga, 1997. Print.

Suriamiharja, A. dkk. Petunjuk praktis menulis. Jakarta: Depdikbud, 1996. Print.

Tampubolon. Kemampuan membaca: teknik membaca efektif dan efisien. Bandung: Angkasa, 1987. Print.

Tarigan, H.G. Membaca sebagai suatu keterampilan berbahasa. Bandung: Angkasa, 1988. Print. . Menulis sebagai suatu keterampilan berbahasa. Bandung: Angkasa, 2008. Print.

Wiryodijoyo. Membaca: strategi pengantar dan teknisnya. Jakarta: Depdikbud, 1989. Print. 